Finisterra, XXXVI, 72, 2001, pp. 141-147

\title{
A MÃE PROMÍSCUA: SOBRE NATUREZA E PAISAGEM
}

\author{
MARIa LÚCIA LEPECKI ${ }^{1}$
}

«No começo era a natureza.»

Camille Paglia

«O que mais há na terra, é paisagem.»

José SARAMAgo

"L'art d'être ennuyeux c'est de tout dire.» ${ }^{2}$

Foi há mais de vinte anos. Estava o António José Saraiva preparando uma comunicação a apresentar em congresso camoniano. Sabia perfeitamente que ideias desejava pôr, que fundamentos textuais para elas aduzir e bastas vezes me falou de umas e de outras, no bar velho da Faculdade. No falar, não se descortinavam problemas. Tudo mudava quando, sentado o meu caro amigo à mesa da escrita, não lhe saía o texto. Longas semanas andou nisso. Um dia me telefona: «A comunicação já está». Eu: «E como ficou?» Ele: «Saiu-me em poema, parece que tinha de ser».

A historinha serve para documentar, mais uma vez, o quanto a ficção é capaz de construir pensamento sistemático. Há mesmo quem alegue, e parece que com razão, impossibilidade de pensar sem ficcionar. Isso implica, naturalmente, entender ficcionação como o conectar de diferentes. Se este meu texto fosse de Teoria da Literatura, era o bom momento de transitar para um tópico escaldante: a capacidade da poesia, discurso lacunar e sobressaltado, para criar conexões tão nítidas quanto a prosa - embora a nitidez poética tenha a sua específica etiologia (a metáfora), a sua própria sintaxe e o seu particular modo de ser. Mas este não é um texto de Teoria da Literatura. De modo que volto ao meu problema: como se verá, é o mesmo de António José Saraiva.

\footnotetext{
1 Professora Catedrática da Faculdade de Letras da Universidade de Lisboa, E-mail spqr@esoterica.pt

2 Encontra-se em várias biografias de Churchill esta frase, de que se diz ter sido uma das citações preferidas do político inglês. Infelizmente, em nenhum lado encontrei indicação de autoria.
} 
O título deste artigo articula " natureza»e «paisagem»-e eu sei porque o pus assim. Não ignoro também o que quero dizer - e até já o veiculei oralmente, embora não no bar da Faculdade, aos meus habituais interlocutores. Estou, entretanto e lamentavelmente, na exacta situação vivida pelo meu amigo: não encontro maneira de escrever dentro do quadro e sobretudo da atmosfera discursiva de um ensaio propriamente dito. Valendo-me, então, da experiência alheia, vou contar uma historinha.

Imaginemos que estou a brincar aos Reis Mandados e me apresentaram, perfeitamente destacadas de qualquer contexto, as duas primeiras citações da epígrafe... Apresentaram-nas e ordenaram: glose isso em texto escrito, com o quanto baste de postura sistemática e consultando, obrigatoriamente, apenas dicionários de línguas - não menos que três, não mais que seis, e nunca dois da mesma língua. Em tempo, acrescentam: e administre os recursos para atingir esta finalidade dentro do espírito da frase de que o Churchill tanto gostava e pela qual também você rói antiga paixão. Tente não ser maçadora, isso também faz parte da regra do jogo. Dou as ordens como boas, que remédio, e ajeito o corpo para o kick-off.

\section{PRIMEIRO TEMPO}

A minha estratégia será tomar uma palavra a Paglia, outra a Saramago e, com a ajuda delas, partir no encalço do pensamento. A primeira dificuldade é a escolha. Opto pelos substantivos, mais rentáveis, como toda a gente sabe, ou crê saber, a menos, naturalmente, que queiramos arbitrar o contrário. Mas fico nos substantivos, e inscrevo, no écran mental: "começo», "natureza», "terra», «paisagem». Sendo a regra do jogo apenas uma palavra por citação, decido-me: «natureza» e "paisagem», tanto fazendo nesta ordem como na inversa. Ou pelo menos assim parece, por enquanto. Despachada a bola, passo ao ataque. Fase inicial: dicionários.

Para Aurélio Buarque de Holanda, paisagem é «espaço de terreno que se abrange num lance de vista» ${ }^{3}$. Enquanto isso saberemos, com Palazzi, ser paesaggio "aspetto di paese campestre o montano», ideia também veiculável com as palavras "panorama, paese, vista, veduta» ${ }^{4}$. Propõe-nos o Larousse entender, por paysage, "étendue de pays qui s'offre à la vue», acepção logo inflectida para "une telle étendue, caractérisée par son aspect» ${ }^{5}$. Finalmente,

\footnotetext{
3 Holanda Ferreira, Aurélio Buarque de (1975) - Novo Dicionário da Língua Portuguesa. Nova Fronteira, Rio de Janeiro.

4 PalazzI, Fernando (1957) - Novissimo Dizionario della Lingua Italiana. Casa Editrice Ceschina, Milano.

5 Péchoin, Daniel; Demay, François (dir.) (1988) - Petit Larousse Illustré. Librairie Larousse, Paris.
} 
entenderá um espanhol por paisaje uma "porción de terreno considerada en su aspecto artístico» ${ }^{6}$. Anotando de passagem que todos os dicionários citados também referem, para a palavra em causa, a acepção de pintura, quadro, onde se representa um lugar natural, saio à procura do que nos reserva natureza.

«[T]odos os seres que constituem o Universo», eis a primeira acepção em Buarque de Holanda. Na mesma posição, em Palazzi, vemos natura como «energia operante nell'universo», só depois se registando "l'universo considerato nella sua forma o nei suoi fenomeni». Enquanto isso, o Larousse dirá, de nature «ensemble des êtres et des choses qui constituent la réalité», enriquecendo depois a palavra, como aliás também fazem as outras minhas fontes, com: «ensemble du monde physique, considéré en dehors de l'homme» e "ensemble de ce qui, dans le monde physique, n'apparaît pas comme transformé par l'homme». Curiosamente, e para finalizar, a Real Academia Española, preferiu organizar o verbete começando do filosófico, teológico e moral, só na terceira acepção trazendo o que a qualquer de nós ocorreria ser a mais natural natureza da natureza: "conjunto, orden y disposición de todas las entidades que componen el universo».

Chegada a esse ponto, e estando previsto na regra do jogo o uso de até seis dicionários, recuo ao indo-europeu, onde talvez encontre ajuda para fabricar pensamento a partir de noções que, ainda vagas, de qualquer modo vão anunciando possíveis ideias, isso se eu conseguir lá chegar. Olhando o indo-europeu, tomo conhecimento de que a raiz pag-, ou pak-, guardava o sentido de «fixer, matériellement et moralement», segundo informa Grandsaignes d'Hauterive ${ }^{7}$. Atento no facto de d'Hauterive ligar «materialmente» e «moralmente» com a conjunção aditiva «e» - opção sintáctica susceptível de carretar, para qualquer argumentação, implicações diferentes das propiciadas pela alternativa "ou». Do sentido material, ligado sobretudo a pag-, advieram, para o que nos interessa, o latim pagus, "território delimitado» bem como paganus e a forma hipotética pagensis, de onde, através do francês, nos chegou paisagem. Enquanto isso, o pak-, a que a minha fonte atribui «sentido moral» deu nascimento, em latim, a pax «convention entre deux peuples» e pactum. Este parentesco, à primeira vista estranho, pode ter, digo-me eu sempre atenta ao jogo, consequências para o que vou tentando pensar. Mas, por enquanto, não sei. E se o vier a saber, nada garante que o direi: «l'art d'être ennuyex», etc. e tal, como o Mandante alertou. Então continuo, agora visitando as remotas origens da palavra natureza.

Descende ela da raiz gen-, ou gne-, «naître, engendrer», de onde temos, em latim, tanto generare quanto natura. Desta, a primeira acepção registada por

6 Real Academia Española (1950) - Diccionario Manual e Ilustrado de la Lengua Española. Editorial Espasa Calpe, Madrid.

7 D'Hauterive, R. Grandsaignes (1948) - Dictionnaire des Racines des Langues Européennes. Librairie Larousse, Paris. 
Gaffiot $^{8}$ (e acabei de esgotar o número permitido de dicionários) é «le fait de la naissance». Só na quinta acepção deparamos com «[...] ensemble des êtres et des phénomènes, monde physique, monde sensible».

\section{TEMPO COMPLEMENTAR}

Posto o precioso apoio dos lexicógrafos, avança-se para a segunda parte da brincadeira, tentando constituir ideia e, sendo possível, pensamento, em obediência à ordem do Rei Mandante.

Direi para mim mesma, em estratégia de auto-motivação, o seguinte: sendo produzir pensamento e produzir ficção uma só e a mesma coisa, na medida em que ambos dependem de conexão de diferentes (mesmo, até, de opostos), todo acto pensante é encontro de uma novidade que se tenta verbalizar, não necessariamente dando uma resposta. Muito embora, também é verdade, ninguém nos proíba de responder.

Escusado dizer que a novidade pode ser uma invenção estratégica. E ficcionamos (no sentido, aqui, de «imaginamos»), um estado de inocência, uma inaugural relação, com um tópico qualquer. Quer a novidade seja real (dimanando de diferença, oposição, incompatibilidade de facto presente entre os elementos concretos que se está a tentar conectar) quer ela seja ficcionada, o resultado é sempre o mesmo: nasce um entendimento novo, ainda que fingido. Trata-se, no fundo, de uma forma de exercitar a reflexão, por recurso a uma espécie de dramatização.

Como poderei, então, articular diferentes nas acepções arroladas para «natureza» e "paisagem»?

Em primeiro lugar, noto que as minhas fontes registam sempre, para natureza, o conceito de totalidade máxima: universo, conjunto de seres e coisas constitutivas da realidade. Há quem separe claramente natureza e homem: «exterior a ele», disseram-nos, ou "por ele não transformado». A essa altura, posso levar a bola pela lateral, dando forma a um embrião de jogada. Como aceitar para a natureza o estatuto de «exterior ao homem», se este é, antes de mais, um ser natural? E será sensato pensar a natureza como «mundo físico não transformado pelo homem»? Mesmo se não modificássemos o corpo físico da natureza (por exemplo, cavando minas, plantando florestas ou construindo cidades), parece impossível qualquer relação com ela sem a transformarmos, por atribuição de sentido. Assim, afigura-se que nem toda transformação da natureza é visível ao olhar do corpo, embora o olhar do discurso a possa sempre perceber. Este olhar do discurso, transformação não impressa no conjunto físico, realidade em si mesma, de todos os seres que constituem o universo,

8 Gaffiot, F. (1994) - Dictionnaire Latin Français. Hachette, Paris. 
acaba por ser a nossa consciência, a única consciência que podemos ter, da existência da natureza.

Relendo o último parágrafo, apercebo-me: já comecei a tratar a paisagem, sem aviso prévio. O Rei Mandante sancionará, certamente, um discurso modelo alho com bugalho. De modo que tento ajeitar a exposição. E a melhor maneira de o fazer é conectar o campo semântico de circunscrição, recorte, parte, presente nos verbetes sobre paisagem, com o campo semântico da totalidade, que vimos nas entradas sobre «natureza». Com isso fabriquei uma hipótese de ligar opostos, o que talvez prove que nem toda mistura alho-bugalho é censurável.

A primeira consequência de uma tal conexão é óbvia: temos de considerar a paisagem como um constituído, quer dizer, como resultante de uma relação cognoscente que destaca, autonomiza, um segmento de totalidade: o mundo natural ${ }^{9}$, qualquer que seja o entendimento que de «natural» tenhamos. Esta relação cognoscente é reiteradamente ficcionante, porque selectiva, de um lado, e hermenêutica, de outro. Além disso, qualquer trabalho selectivo tem dois níveis, realizados, ao que parece, simultaneamente. No primeiro nível seccionamos, no caso dentro do continuum natural, uma espécie de «extensão de terreno", um lugar. O próprio percurso da tesoura, ou do bisturi, dá, desde o início da operação, testemunho de um outro movimento, o interpretativo: atribuímos semântica àquele 'pedaço de realidade', desta forma transmutando lugar em espaço. Olhando a secção assim destacada da totalidade dos corpos constitutivos do universo, já poderei verbalizar o que ali se me afigura estar em termos de conteúdo de sentido: é «tenebroso», ou «alegre», ou «calmo». Junto com a atribuição de conteúdo de sentido, potencio para a paisagem um estatuto de sujeito: de facto, ela assume (dependendo isto apenas da nossa escolha discursiva) capacidade de actuação, o que me permite dizer «esta paisagem me tranquiliza, ou alegra, ou amedronta». A retórica do discurso reconhece estas situações como pertencentes ao campo metafórico, e as chama por dois nomes, conforme o caso: animização ou antropomorfização. A primeira, podendo surgir sozinha, é sempre condição da segunda, dado não se conhecerem casos de anthropos destituído de anima.

Instituir a paisagem como sujeito de acção tem a ver, creio eu, com a questão do pacto. Na verdade, não posso eu ser sujeito em relação alguém ou a algo, se ele não for sujeito para mim. O estatuto criado é de diálogo, por consequência de igualização. Mais uma nota é importante: na troca entre mim e a

9 Talvez devamos considerar também como paisagem uma proposta teórica, expressa em pura linguagem simbólica: aqui os conceitos se relacionam harmonicamente, no quadro da definição de espaço de Alexandrov (cf. Lotman, I., 1973, La Structure du Texte Artistique. Éditions Gallimard, Paris). Parece lógico que recortar secções do entendimento, relacionando e harmonizando (espacializando) conceitos representáveis apenas em discurso teórico-simbólico, implica o abandono, esquecimento, de outras possibilidades combinatórias, tal como ocorre nos recortes feitos, para formar paisagens sobre a totalidade da natureza. 
paisagem, na inscrição que nela faço da minha própria e humana natureza, trago sempre e inapelavelmente todo o meu cabedal interior. E a paisagem vista, pensada e sentida é ao mesmo tempo, e indissoluvelmente, tanto natureza recortada quanto uma nova organização da minha pessoa. Se for como proponho, será injusto dizer da paisagem: "é o meu outro». Mais sensato será pensarmos nela como a sempre renovada forma de nós sermos nós mesmos.

\section{DECISÃO A PENALTIS}

Se para constituir paisagem compulso biografia e memórias, também tenho de actuar sobre esquecimentos. Estes incidem em dois planos. Primeiro, esqueço o que deixei de fora da moldura do recorte, embora aqui, e a bem da verdade, se deva dizer que o esquecimento não é total. Referindo de lembrança - já se me esgotaram as consultas permitidas - a observação de Iouri Lotman sobre a comunicação cinematográfica, tudo se passa como numa sala de cinema: o que está de fora do écran, também significa, nas ausências latejando, compulsivas, outras tantas presentificações. Se, perante a natura recortada eu, lembrando, também deslembro, subjaz em mim a noção de que a paisagem constituída é uma entre muitas susceptíveis de serem organizadas a partir de um mesmo segmento destacado da inteireza do universo. Isto, naturalmente fascina, pois me obriga a constatar uma novidade. Se a natureza, na sua pluralidade de corpos e de combinatórias, é fonte de infinitos processos interiores, intelectuais e afectivos, o mesmo parece acontecer com a paisagem, a quem não parece justo negar a infinita capacidade metamórfica, nascida com as novas opções sintácticas que os sucessivos olhares vão criando nas revisitações de um mesmo recorte. De uma certa forma, e obrigatoriamente, toda paisagem é naturante, tal como a natureza o é. Da naturância nasce a diferença e desta a processualidade, por outras palavras, a história.

Estando o tempo de jogo quase no fim, gostava de colocar mais uma aproximação entre, de um lado, natureza e paisagem e, de outro, a retórica do discurso. É a seguinte:

Para trazer à consciência um recorte de natureza e os corpos nele contidos, passo por alguns processos verbais, mesmo que disso não me dê conta. O primeiro processo, distinguindo partes autónomas do recorte, diz-lhes os nomes: em Retórica chama-se a isto nomeação. Como estamos a olhar a inteireza do segmento seccionado, a nomeação se faz sequencialmente, assim atendendo à pluralidade dos corpos. Por causa do dizer sequenciado, a Retórica reconhece o recurso que dá pelo nome de enumeração, espécie de porta por onde se ingressa no domínio da sintaxe. Depende da sintaxe, então, não apenas a existência do todo recortado como, ainda, a articulação lógica das partes do recorte, para elas poderem ser vistas como conjunto, termo que tanto a Retórica quanto a Matemática utilizam para referir realidades perfeitamente equivalentes no plano das linguagens natural e simbólica. Então, perante um recorte dado, 
suponhamos, «encosta de montanha» eu digo, por exemplo: aclive, mato, bosques, afloramentos graníticos, um castanheiro e um pinheiro. Desta sequência de palavras resulta, para o meu interlocutor, imagem que poderá ser infinitamente pormenorizada quando, referindo mais e mais corpos e partes deles, com suas nuances milimétricas de linhas, cores e o mais que for preciso, eu entro definitivamente no campo da descrição.

O processo nomeação-enumeração não é, de modo algum, inocente. Na verdade, tudo indica que nomeamos e enumeramos em ordem decrescente de valor, começando do que mais nos toca e impressiona, para chegar, no final do percurso, ao menos importante. Dito isso, parece claro que nomear e enumerar é, também, hierarquizar. Para mim mesma ou para um possível interlocutor a quem me dirija, o corpo escolhido para iniciar a enumeração forma o primeiro plano da paisagem, ajeitando-se os outros em direcção ao fundo, até esbaterem-se, pouco nítidos, no horizonte da minha percepção. Esta composição circunscreve limites externos (os que diferenciam a paisagem como um todo destacado de - mas sempre coexistente com - o todo total da natureza) e limites internos. Dentro dos últimos, outros limites, cada vez mais reduzidos, separarão corpos de corpos e, ainda, partes de partes de um mesmo corpo. Caso em que, contemplando a minha encosta de montanha, verei galhos, agulhas e pinhas no pinheiro ou, galhos, folhas e castanhas no castanheiro...

Pensada desta maneira, a paisagem resulta do exercício da inteligência enquanto discriminação: separamos coisas de coisas, águas de águas se for preciso, como se conta ter acontecido na criação do mundo. E o Deus do Génesis terá sido quem primeiro fixou «moral e materialmente» a potencialidade infinita do caos inicial, imagem por excelência, no mito fundador que nos rege, da força naturante da natureza. Aprendendo com o Deus do Génesis, também nós nos tornámos capazes de fazer luz, em sistema de corte e cola, sobre a totalidade do universo, sobre a sua variedade sem fim, sua pujança e potencialidade combinatória.

Separando, discriminando, ordenando e, ao nosso arbítrio, tornando a juntar, criamos mais e mais paisagens. Com isso obedecemos à compulsão do encontro com as origens, através da comunhão com o corpo sagrado, desde sempre promíscuo e genesíaco, da Mãe Natureza. 